\title{
Analisis pengaruh pengetahuan awal, efikasi diri, kecerdasan emosional, perilaku belajar, dan budaya terhadap tingkat pemahaman akuntansi mahasiswa perbankan syariah
}

\author{
Fany Indriyani ${ }^{1, *}$ \\ ${ }^{1}$ Fakultas Ekonomi dan Bisnis Islam IAIN Salatiga, Indonesia \\ *) Korespondensi (e-mail: fanyindriyani@iainsalatiga.ac.id) \\ Received: 01-April-2021; Revised: 25- April-2021; Accepted: 28- April 2021
}

\begin{abstract}
The study aimed to examine the effect of prior knowledge, self-efficacy, emotional intelligence, learning behavior, and culture on the level of significance accounting understanding of Islamic banking students in Salatiga. This study uses primary data by providing questions in the form of questionnaires distributed to respondents who are students of the Islamic Banking Study Program, Faculty of Economics and Islamic Business, IAIN Salatiga. The sample was selected using the purposive sampling method. A total number of 180 questionnaires were sent out and 160 questionnaires can be processed. The data is processed by multiple linear regression analysis to prove the hypothesis. The results showed that partially the effect of prior knowledge has a significant effect on accounting understanding, although the four other variables, namely self-efficacy, emotional intelligence, learning behavior, and culture have no effect on the level of accounting understanding of Islamic banking students in other cities.
\end{abstract}

Keywords: Culture, Emotional Intelligence, Learning behavior, Self-efficacy.

\begin{abstract}
Abstrak
Penelitian ini bertujuan untuk menguji pengaruh pengetahuan awal, efikasi diri, kecerdasan emosional, perilaku belajar, dan budaya terhadap tingkat pemahaman akuntansi mahasiswa perbankan syariah di iain salatiga. Penelitian ini menggunakan data primer yaitu dengan menyediakan pernyataan dalam bentuk kuesioner yang dibagikan kepada responden yang merupakan mahasiswa Program Studi Perbankan Syariah Fakultas Ekonomi dan Bisnis Islam IAIN Salatiga. Sampel dipilih dengan menggunakan metode purposive sampling. Sebanyak 180 kuesioner yang dikirim dan 160 kuesioner yang dapat diolah. Data diolah dengan analisis regresi linear berganda untuk membuktikan hipotesis. Hasil penelitian ini menunjukkan bahwa secara parsial pengaruh pengetahuan awal berpengaruh signifikan terhadap pemahaman akuntansi meskipun keempat variabel lain, yaitu efikasi diri, kecerdasan emosional, perilaku belajar, dan budaya tidak berpengaruh terhadap tingkat pemahaman akuntansi mahasiswa perbankan syariah.

Kata kunci: Budaya, Efikasi diri, Kecerdasan emosional, Perilaku belajar.

How to cite: Indriyani, F. (2021). Analisis pengaruh pengetahuan awal, efikasi diri, kecerdasan emosional, perilaku belajar, dan budaya terhadap tingkat pemahaman akuntansi mahasiswa perbankan syariah. Journal of Accounting and Digital Finance, 1(1), 1-14.
\end{abstract}

\section{Pendahuluan}

Akuntansi merupakan salah satu mata kuliah wajib pada program studi perbankan syariah di Istitut Agama Islam Negeri (IAIN) Salatiga. Namun, latarbelakang jenjang 
pendidikan sebelumnya atau setingkat SMA sederajat pada mahasiswa IAIN Salatiga, sangat heterogen. Keberagaman latarbelakang pendidikan ini sangat mempengaruhi daya pemahaman mahasiswa khususnya terkait dengan mata kuliah akuntansi. Pemahaman akuntansi bermanfaat untuk mempermudah mahasiswa dalam menghadapi mata kuliah lanjutan, dan bahkan berguna bagi lulusan program sarjana perbankan syariah terkait dengan keterampilan yang komprehensif dalam dunia perbankan.

Pemahaman adalah kemampuan seseorang untuk mengerti atau memahami sesuatu setelah sesuatu itu diketahui dan di ingat (Bloom, 1984), maka pemahaman akuntansi merupakan kemampuan seseorang mendefinisikan dan merumuskan akuntansi dengan perkataannya sendiri berdasarkan apa yang telah dipelajari. Pemahaman seorang mahasiswa terhadap materi akuntansi akan ditunjukkan melalui IPK dan penguasaan konsep yang terkait. Menurut Suwardjono (2001) pengetahuan terhadap ilmu akuntansi dapat dipandang dari dua sisi pengertian yaitu: (1) pengetahuan profesi (keahlian) yang dipraktekan di dunia nyata dan (2) disiplin pengetahuan yang diajarkan di perguruan tinggi.

Pengambilan mata kuliah Pengantar Akuntansi mahasiswa Perbankan Syariah IAIN Salatiga, biasanya dilakukan diawal semster. Hal ini menandakan bahwa mata kuliah pengantar akuntansi memegang peranan penting dalam mengantarkan mahasiswa perbankan syariah dalam memahami mata kuliah berikutnya. Sebagai salah satu mata kuliah dasar, akuntansi diberikan untuk memberikan pengetahuan dasar atau fundamental kepada mahasiswa.

Penelitian ini menggunakan variabel pengetahuan awal, efikasi diri, kecerdasan emosional, perilaku belajar dan budaya untuk mengetahui tingkat pemahaman mahasiswa perbankan syariah IAIN Salatiga terhadap materi akuntansi. Penggunaan variabel tersebut terbukti signifikan pada beberapa penelitian sebelumnya, sehingga dengan menggunakan variabel yang sama, diharapkan penelitian ini dapat menemukan tingkat keberhasilan belajar yang dicapai oleh peserta didik.

Pengetahuan awal merupakan materi akuntansi yang diperoleh mahasiswa dari proses pembelajaran jenjang sebelumnya atau setingkat SMA sederajat. Pengetahuan awal juga berasal dari sikap dan pengalaman yang telah dimiliki mahasiswa selama belajar. Kujawa \& Huske (1995) merumuskan pengertian Prior Knowledge sebagai: "a combination of the learner's preexisting attitudes, experiences, and knowledge. Rumusan ini menunjukkan bahwa Prior Knowledge tidak hanya berkaitan dengan aspek pengetahuan saja, tetapi juga menyangkut sikap dan pengalaman yang telah dimiliki seorang pembelajar.

Penelitian tentang pengetahuan awal masih menampakkan hasil yang tidak konsisten pada beberapa penelitian. Penelitian yang dilakukan oleh (Taufiq, 2017) menunjukkan bahwa pengetahuan awal tidak dapat berpengaruh signifikan jika pengujian dilakukan secara parsial, namun pengujian simultan dengan beberapa factor menghasilkan nilai yang baik terhadap pemahaman akuntansi. 
Selain pengetahuan awal, efikasi diri memiliki pengaruh yang baik dalam menentukan keberhasilan belajar yang akan dicapai oleh peserta didik. Efikasi diri yang tinggi, dipercaya dapat memberikan inisiatif dan ketekunan untuk meningkatkan usaha dan kemampuan seorang untuk mendapatkan apa yang diinginkannya (Taufik, 2017). Self efficacy juga merupakan ekspetasi spesifik yang diyakini mengenai kemampuan dalam mencapai sesuatu atau mengerjakan tugas. Keyakinan atas suatu hal tersebut dapat terwujud dalam magnitude atau keyakinan untuk menyelesaikan tugas yang dianggap sulit, generality atau keyakinan dalam menyelesaikan segala variasi tugas, serta strength atau keyakinan akan kemampuan untuk menyelesaikan tugas (Taylor, 2009).

Hasil penelitian (Merdekawati \& Fatmawati, 2019) menunjukkan pengaruh yang signifikan dari efikasi diri terhadap kemampuan siswa dalam memahami materi akuntansi. Namun tidak demikian dengan hasil penelitian Ayu Arisanti, Devika dan Hakim (2019) yang tidak dapat membuktikan pengaruh efikasi diri terhadap hasil belajar akuntansi biaya mahasiswa.

Faktor penting lain yang dapat menentukan faktor keberhasilan belajar adalah kecerdasan emosi (Emotional Quotient (EQ). Menurut Goleman (2000) bahwa Kecerdasan emosional merupakan kemampuan merasakan, memahami secara efektif dalam penerapan daya dan kepekaan emosi sebagai sumber energi, informasi, koneksi dan pengaruh yang manusiawi.

Kecerdasan emosional berhasil dibuktikan berpengaruh terhadap pemahaman akuntansi siswa (Tjun et al., 2009). Namun hal ini berbeda dengan temuan (Widhianningrum, 2017) yang tidak dapat menemukan pengeruh kecerdasan emosional terhadap kemampuan akuntansi siswa.

Hal lain yang penting dalam mendukung keberhasilan belajar mahasiswa adalah perilaku belajar. Perilaku belajar terdiri dari kebiasaan mengikuti pelajaran, kebiasaan membaca buku, kunjungan ke perpustakaan, dan kebiasaan menghadapi ujian.

Factor perilaku belajar terbukti dapat mempengaruhi pemahaman akuntansi (Mutia, 2015). Namun hal ini tidak sejalan dengan temuan (Agustin \& Sujana, 2018) yang tidak menemukan pengaruh perilaku belajar mahasiswa dengan pemahaman akuntansi.

Terkait dengan prestasi akademik mahasiswa, dalam Framework of Development of Accounting Education Research yang dikeluarakan oleh the American Accounting (AAA) dalam Hariyoga dan Supriyanto (2011) menyatakan bahwa ada pengaruh demografi terhadap prestasi akademik mahasiswa. Lingkup demografi, berdasarkan penelitian sebelumnya, menyebutkan bahwa ternyata faktor budaya merupakan salah satu dimensi dari demografi yang dapat mempengaruhi tingkat pemahaman akuntansi pada mahasiswa perbankan syariah IAIN Salatiga

Hal ini sesuai dengan penelitian yang dilakukan Hikmawati (2019) yang dapat menemukan pengaruh budaya terhadap pemahaman akuntansi, meskipun hal ini bertentangan dengan temuan (Suprianto \& Harryoga, 2016) yang menyatakan tidak ada pengeruh antara budaya dengan pemahaman akuntansi. 
Kebutuhan dunia kerja terhadap lulusan perguruan tinggi tidak hanya terhadap sisi penguasaan ilmu pengetahuan saja, tetapi juga menuntut penguasaan ketrampilan intelektual, interporsonal dan komunikasi serta orientasi professional (Trisniwati dan Suryaningsum, 2003). Oleh karena itu sebagai salah satu penyelenggara pendidikan tinggi di Indonesia, IAIN Salatiga memberikan pengetahuan akuntansi sebagai salah satu bentuk ketrampilan intelektual kepada mahasiswanya. Hal ini dimaksudkan agar lulusannya memiliki kualitas dan kualifikasi yang memadai sebagai tenaga profesional.

Berdasarkan deskripsi pada latar belakang masalah di atas, maka pokok permasalahan dalam penelitian ini yaitu bagaimana pengaruh pengetahuan awal, efikasi diri, kecerdasan emosional, perilaku belajar, dan budaya mahasiswa Perbankan syariah IAIN Salatiga terhadap Pemahaman Akuntansi?

\section{Tinjauan Pustaka}

\section{Belajar humanistik}

Teori ini mengungkapkan bagaimana proses belajar harus dilalui oleh seseorang dalam mencapai suatu pemahaman (Ratnawati, 2016). Penekanan terhadap proses belajar menjadi inti dari teori ini. Hasil akhir yang diharapkan dari proses ini adalah bentuk belajar yang paling ideal dan manusiawi dalam kehidupan sehari-hari dalam rangka mencapai aktualisasi diri. Teori ini juga dikenal sebagai teori Bloom dan Krathwohl dalam bentuk taksonomi Bloom.

Bloom dan Krathwohl menunjukkan beberapa prilaku yang dilakukan oleh siswa, adalah: Kognitif, Psikomotor, dan Afektif. Taksonomi Bloom ini, banyak membantu praktisi pendidikan untuk memformulasikan tujuan belajar dalam bahasa yang mudah dipahami dan terukur. Disamping itu, teori Bloom juga banyak dijadikan pedoman untuk membuat soal ujian.

\section{Pemahaman akuntansi}

Pemahaman akuntansi merupakan kemampuan mahasiswa dalam mengerti dan memahami materi yang terkait dengan bidang akuntansi. Menurut Suwardjono (2001) pengetahuan terhadap ilmu akuntansi dapat dipandang dari dua sisi pengertian yaitu: (1) pengetahuan profesi (keahlian) yang dipraktekan di dunia nyata dan (2) disiplin pengetahuan yang diajarkan di perguruan tinggi. Sehingga akuntansi merupakan seperangkat pengetahun untuk menghasilkan sesuatu (goods) yang bermanfaat.

Akuntansi jika dipandang sebagai sains dan teknologi menghasilkan dua pandangan, yaitu teori akuntansi positif dan teori akuntansi normatif. Teori akuntansi positif berisi pernyataan tentang suatu kejadian atas dasar pengamatan empiris. Sedangkan, teori akuntansi normatif berisi tentang pernyataan atau penalaran yang dilandasi oleh pertimbangan nilai. Teori akuntansi positif erat kaitannya dengan akuntansi sebagai sains, sementara itu teori akuntansi normatif erat kaitannya dengan akuntansi sebagai teknologi.

Akuntansi sebagai teknologi menuntut penalaran logis untuk dapat memberikan alasan tentang pemberlakuan praktik akuntansi tertentu. Penalaran merupakan proses 
berpikir logis dan sistematis untuk membentuk dan mengevaluasi suatu keyakinan (Suwardjono, 2010).

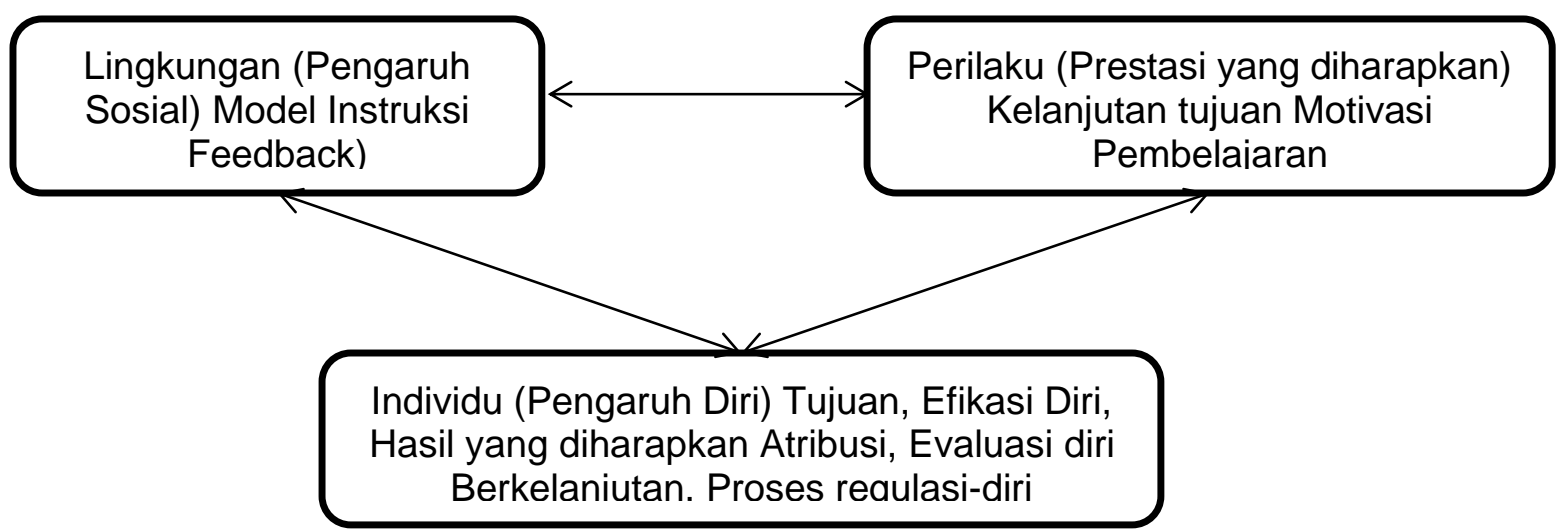

Gambar 1. Bagan triadik resiprokal dari Albert Bandura

\section{Kerangka konsep dan hipotesis}

Sumber: Woolfolk, 2007.

Pendidikan merupakan salah satu usaha manusia dalam angka meningkatkan taraf hidupnya. Sehingga pendidikan tidak hanya mengandung unsur pembelajaran secara teoritis, tetapi juga aspek implikasi seperti perkembangan emosi, fisik, mental, etika/prilaku, kepercayaan akan kemampuan personal dan seluruh aspek perkembangan manusia lainnya (Hariyoga dan Supriyanto, 2011).

Salah satu faktor pendukung keberhasilan dalam pendidikan adalah pemahaman yang baik. Pemahaman merupakan salah satu faktor yang dapat mendukung keberhasilan proses belajar. Untuk melihat berbagai faktor yang mempengaruhi pemahaman, maka berikut ini adalah indikator pembentuk pemahaman yaitu:

$\mathrm{H1}$ : Pengetahuan Awal Berpengaruh signifikan terhadap pemahaman akuntansi

H2: Efikasi diri berpengaruh signifikan terhadap pemahaman akuntansi

H3: Kecerdasan Emosional berpengaruh signifikan terhadap pemahaman akuntansi

H4: Perilaku Belajar berpengaruh signifikan terhadap pemahaaman akuntansi

H5: Budaya berpengaruh signifikan terhadap pemahaman akuntansi

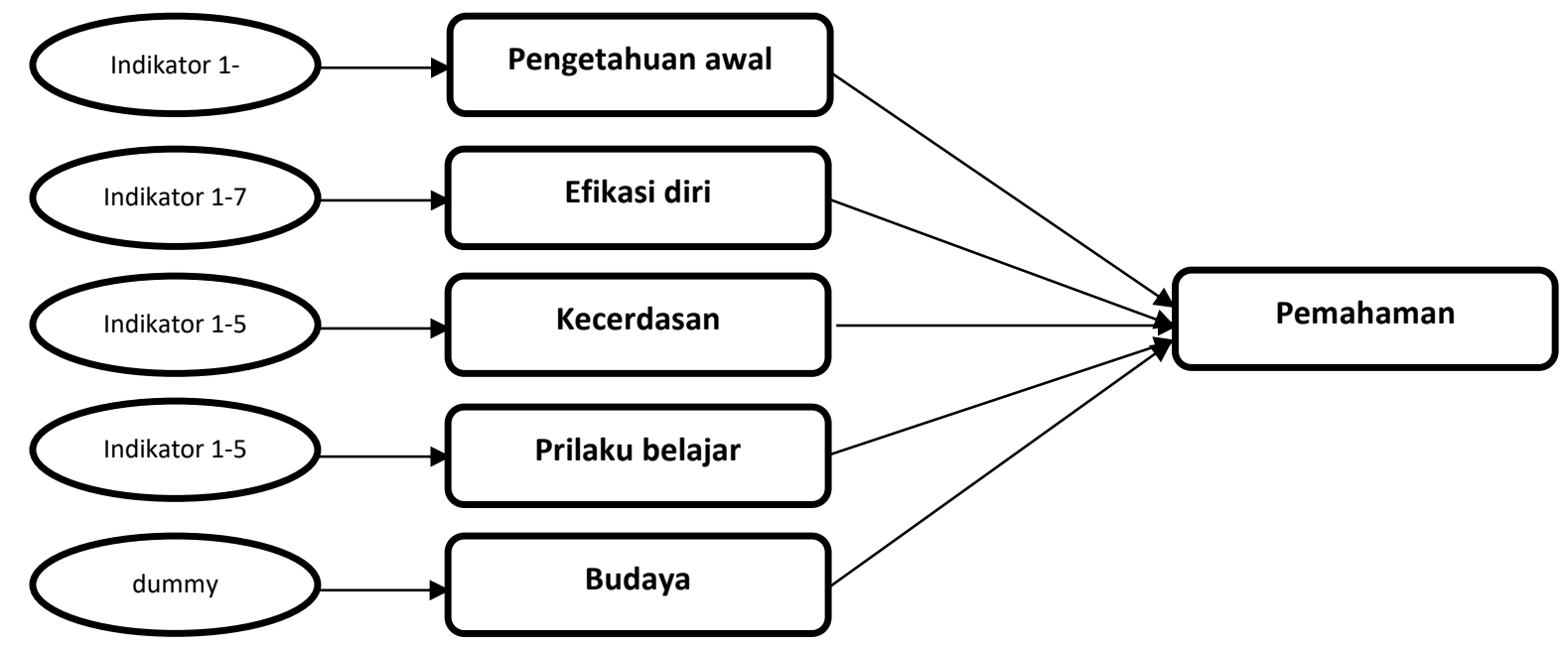

Gambar 2. Kerangka penelitian 


\section{Metode Penelitian}

Penelitian ini dilakukan dengan pendekatan kuantitatif. Metode kuantitatif merupakan penelitian dengan data berupa angka dan asumsinya positivisme dengan menggunakan instrument guna menguji hipotesis yang telah ditetapkan (Sugiyono, 2016). Penelitian ini dilakukan di Fakultas Ekonomi dan Bisnis Islam IAIN Salatiga dengan menyebarkan kuisioner kepada mahasiswa S1 Perbankan Syariah angkatan 2016. Objek penelitian ini adalah pengetahuan awal akuntansi (X1), efikasi diri (X2), kecerdasan emosional (X3), perilaku belajar (X4), dan budaya (X5). Adapun variable dependen penelitian ini adalah pemahaman akuntansi yang diperoleh dari nilai mata kuliah pengantar akuntansi.

Penelitian ini mengambil populasi mahasiswa perbankan Syariah angkatan 2016 yang telah menempuh 100 sks dengan asumsi mahasiswa telah menempuh mata kuliah pengantar akuntansi dan mendapatkan nilai atas mata kuliah tersebut, sebagai pengukur variable pemahaman akuntansi. Cara pengambilan sampel dilakukan dengan nonpropability sampling. Penyebaran kuisioner dilakukan terhadap 180 mahasiswa dan hasil kuisioner yang berhasil diolah hanya 160 data. Populasi dalam penelitian adalah mahasiswa IAIN Salatiga. Pemilihan responden dilakukan dengan menggunakan metode purposive sampling. Pemilihan sampel secara tidak acak dengan beberapa kriteria sebagai berikut: pertama, Mahasiswa perbankan syariah semester 5. Kedua, Mahasiswa perbankan syariah (S1) di IAIN Salatiga.

Jenis data yang digunakan dalam penelitian ini adalah data primer. Data primer merupakan data yang diperoleh langsung dari sumber langsung tanpa melalui media perantara. Pada penelitian ini data diperoleh langsung dari kuisioner yang diisi oleh responden, yaitu mahasiswa semester 5 S1 perbankan Syariah FEBI IAIN Salatiga. Angket yang disebar telah valid dan reliabel.

Alat analisis dalam penelitian ini adalah regresi berganda. Regresi linier berganda digunakan untuk mengetahui bagaimana pengaruh variable independent terhadap variabel dependen. Adapun persamaan regresi linier berganda sebagai berikut:

$$
Y=\beta_{0}+\beta_{1} X_{1}+\beta_{2} X_{2}+\beta_{3} X_{3}+\beta_{4} X_{4}+\beta_{5} X_{5}+\varepsilon
$$

Keterangan:

$\mathrm{Y}$ : Pemahaman akuntansi

$\mathrm{X}_{1}$ : Pengetahuan awal

$\mathrm{X}_{2}$ : Efikasi diri

$\mathrm{X}_{3}$ : Kecerdasan emosional

$\mathrm{X}_{4}$ : Perilaku belajar

$\mathrm{X}_{5}$ : Budaya

$\beta_{0}$ : Konstanta

$\beta_{1-5}$ : Koefisien

$\varepsilon \quad:$ eror term

\section{Definisi operasional variabel}

Definisi operasional variabel merupakan variabel pengukur penelitian. Berdasarkan model, maka variabel-variabel yang digunakan adalah: 
1. Pemahaman Akuntansi diukur dengan nilai akhir mata kuliah Pengantar Akuntansi,

2. Pengetahuan Awal Akuntansi (Prior Knowledge), diukur dengan 10 indikator sebagaimana dilakukan oleh Taufiq (2015), yaitu: (1). Proses dan Konten Belajar, (2). Tujuan Pembelajaran, (3). Tujuan pribadi mahasiswa, (4). Memiliki keyakinan diri, (5). Kesadaran pada minat diri, (6). Memiliki kekuatan diri, (7). Memiliki motivasi diri, (8). Aktivitas yang dilakukan mahasiswa, (9). Pengalaman di lingkungan keluarga, dan (10). Pengalaman di lingkungan teman sebaya.

3. Efikasi Diri (Self Eficacy). Variabel efikasi diri terdiri atas 7 indikator yang diambil dari penelitian yang telah dilakukan oleh Bandura (1997) dan Taufiq (2015) terdiri dari (1). Mahasiswa yakin mampu memahami materi yang sulit, (2). Mahasiswa yakin mampu mengatasi hambatan dalam tingkat kesulitan tugas yang dihadapinya, (3). Mahasiswa berminat pada materi pembelajaran akuntansi, (4). Mahasiswa yakin memiliki kemampuan dalam berbagai macam tugas, (5). Mahasiswa yakin bahwa usaha yang dilakukan dapat mencapai tujuan dan tuntunan yang harus dicapai, (6). Mahasiswa mampu memecahkan masalah, (7). Mahasiswa yakin pengalaman buruk tidak akan menghalangi pencapaian keberhasilan,

4. Kecerdasan Emosional $(E Q)$, Variabel Kecerdasan emosional diukur dengan lima dimensi (Rissyo Melandry dkk., 2007). Kelima dimensi tersebut adalah sebagai berikut: (1) Pengenalan Diri, (2) Pengendalian Diri, (3) Motivasi Diri, (4) Empati, dan (5) Kemampuan Sosial.

5. Perilaku Belajar, Variabel Perilaku Belajar diukur dari empat dimensi yang berhubungan erat dengan perilaku belajar yaitu: (1) Kebiasaan mengikuti pelajaran, (2) Kebiasaan memantapkan pelajaran, (3) Kebiasaan membaca buku,

(4) Kebiasaan menyiapkan karya tulis, dan (5) Kebiasaan menghadapi ujian (Suwarjono, 1991)

6. Budaya, Variabel budaya akan diukur menggunakan variabel dummy dengan 1, Suku Jawa, 0 = Selain Suku Jawa

Instrumen Pengetahuan Awal Akuntansi $\left(X_{1}\right)$, Efikasi diri $\left(X_{2}\right)$, Kecerdasan Emosional $\left(X_{3}\right)$, Perilaku Belajar $\left(X_{4}\right)$ dan Budaya $\left(X_{5}\right)$ diukur dengan menggunakan skala likert 1-7. Sedangkan pengukuran tingkat pemahaman akuntansi dilihat dari hasil yang dicapai oleh mahasiswa dalam kegiatan belajar yang tercermin dari nilai pengantar akuntansi.

\section{Asumsi klasik model regresi linear}

1. Uji normalitas dilakukan dengan menggunakan alat uji Kolgomorov-Smirnov yang bertujuan untuk menguji kelayakan model regresi karena telah memenuhi asumsi normalitas bebas dari bias (BLUE).

2. Multikoliniearitas merupakan interkolerasi antara variable bebas yang menunjukkan adanya hubungan signifikan yang lebih dari satu. Jika nilai koefisien korelasi variable terletak diluar batas maka hal tersebut menunjukkan terjadinya multikoleniearitas. 
3. Pengujian ini dilakukan untuk mengetahui adanya pola tertentu yang dapat menyebabkan gejala heterokedastisitas. Uji heterokedastisitas dapat dibuktikan dengan uji Glejser.

4. Autokorelasi muncul karena observasi yang berurutan sepanjang waktu berkaitan satu sama lainnya. Hal ini disebabkan karena nilai residu tidak bebas dari satu observasi ke observasi lainnya. Model regresi yang baik adalah yang terbebas dari gejala autokorelasi. Salah satu Teknik yang digunakan untuk menguji adalah dengan uji durbin Watson (DW test). Menurut Ghozali (2011) gejala autokorelasi terlihat jika nilai Durbin Watson lebih kecil dari dL atau lebih besar dari 4-dL.

\section{Hasil dan Pembahasan}

\subsection{Hasil penelitian}

\section{Uji validitas dan reliabilitas}

Hasil uji validitas untuk variable pengetahuan awal $\left(X_{1}\right)$, efikasi diri $\left(X_{2}\right)$, kecerdasan emosional $\left(\mathrm{X}_{3}\right)$, Perilaku belajar $\left(\mathrm{X}_{4}\right)$, budaya $\left(\mathrm{X}_{5}\right)$ dan pemahaman akuntansi $(\mathrm{Y})$ dapat dilihat pada table dibawah ini:

1. Hasil uji validitas terhadap 10 item pertanyaan yang terdapat didalam kuisioner yang disebarkan kepada mahasiswa prodi perbankan syariah semester 5 diperoleh nilai $r$ hitung antara 0,691 sampai dengan 0,902 yang lebih besar dari nilai $r$ table 0,361 sehingga 10 pertanyaan dianggap valid.

2. Hasil uji validitas terhadap 7 item pertanyaan yang terdapat didalam kuisioner yang disebarkan kepada mahasiswa prodi perbankan syariah semester 5 diperoleh nilai $r$ hitung antara 0,609 sampai dengan 0,779 yang lebih besar dari nilai $r$ table 0,361 sehingga 10 pertanyaan dianggap valid.

3. Hasil uji validitas terhadap 5 item pertanyaan yang terdapat didalam kuisioner yang disebarkan kepada mahasiswa prodi perbankan syariah semester 5 diperoleh nilai $r$ hitung antara 0,635 sampai dengan 0,893 yang lebih besar dari nilai $r$ table 0,361 sehingga 10 pertanyaan dianggap valid.

4. Hasil uji validitas terhadap 5 item pertanyaan yang terdapat didalam kuisioner yang disebarkan kepada mahasiswa prodi perbankan syariah semester 5 diperoleh nilai $r$ hitung antara 0,549 sampai dengan 0,770 yang lebih besar dari nilai $r$ table 0,361 sehingga 10 pertanyaan dianggap valid.

Hasil pengujian reliabilitas dapat disimpulkan bahwa semua variable yang digunakan dalam penelitian adalah reliabel karean memiliki nilai Alpha Cronbach $(\alpha)$ lebih besar dari 0,60.

\section{Asumsi klasik model regresi linear}

1. Hasil uji normalitas menggunakan metode Kolomogrov Smirnov didapatkan hasil signifikansi dari uji normalitas sebesar 0,099 dimana hasil tersebut lebih besar dari tariff signifikansi 0,05 sehingga dapat disimpulkan bahwa uji tes normalitas pada penelitian ini adalah terdistribusi normal. 
2. Berdasarkan hasil olah data nilai uji multikolinieritas disebut bebas dari gejala jika nilai koefisien VIF lebih kecil dari 10. Pada model, nilai koefisien terjadi antara 1,017 sampai 2,391 yang menunjukkan tidak terjadi gejala multikoliniearitas.

3. Uji glejser untuk menguji adanya gejala heterokedastisitas. Model dinyatakan bebas dari gejala heterokedastisitas jika nilai signifikan masing-masing variable lebih beasr dari 0,05. Variabel independent pada model menunjukkan nilai antara 0,1-0,5 yang menunjukkan tidak ada masalah heterokedastisitas pada model.

4. Menurut Ghozali (2011) gejala autokorelasi terlihat jika nilai Durbin Watson lebih kecil dari dL atau lebih besar dari 4-dL. Nilai menunjukkan angka 2,015 yang lebih besar dari nilai DU $(1,8063)$ dan lebih kecil dari 4-DU $(2,1937)$. Berdasarkan hal tersebut dapat disimpulkan bahwa tidak ada autokorelasi pada model regresi.

\section{Analisis regresi linier berganda}

Pengujian regresi linier berganda digunakan untuk mengetahui bagaimana pengaruh variable independent (pengetahuan awal $\left(X_{1}\right)$, efikasi diri $\left(X_{2}\right)$, kecerdasan emosional $\left(X_{3}\right)$, Perilaku belajar $\left(X_{4}\right)$, dan Budaya $\left(X_{5}\right)$. Pengujian yang telah dilakukan memperoleh hasil sebagai berikut.

Tabel 1. Model Summary

\begin{tabular}{lccccc}
\hline Model & $\mathrm{R}$ & $\begin{array}{c}\mathrm{R} \\
\text { Square }\end{array}$ & $\begin{array}{c}\text { Adjusted R } \\
\text { Square }\end{array}$ & $\begin{array}{c}\text { Std. Error of } \\
\text { the Estimate }\end{array}$ & $\begin{array}{c}\text { Durbin- } \\
\text { Watson }\end{array}$ \\
\hline 1 & $0,226^{\mathrm{a}}$ & 0,051 & 0,020 & 1,03373 & 2,015 \\
\hline $\begin{array}{l}\text { a. Predictors: (Constant), budaya, pengetahuan awal, perilaku belajar, kecerdasan } \\
\text { emosional, efikasi diri, b. Dependent Variable: pemahaman akuntansi }\end{array}$
\end{tabular}

Berdasarkan hasil analisis diperoleh hasil koefisien determinasi berganda $\left(R^{2}\right)$ sebesar 0,51, hal ini berarti 51\% perubahan Pemahaman Akuntansi dipengaruhi oleh pengetahuan awal, efikasi diri, kecerdasan emosional, perilaku belajar dan budaya, sedangkan sisanya sebesar $49 \%$ disebabkan oleh factor lain yang tidak termasuk dalam persamaan regresi yang dibuat.

Tabel 2 Hasil estimasi regresi linear berganda

\begin{tabular}{lrrrr}
\hline \multicolumn{1}{c}{ Variabel } & Koefisien & Std. Errot & t hitung & \multicolumn{1}{c}{ Sig } \\
\hline Konstanta & 2,560 & 0,922 & 2,776 & 0,006 \\
\hline$X_{1}$ & 0,028 & 0,014 & 2,072 & 0,040 \\
\hline$X_{2}$ & 0,023 & 0,024 & 0,926 & 0,356 \\
\hline$X_{3}$ & $-0,025$ & 0,030 & $-0,837$ & 0,404 \\
\hline$X_{4}$ & $-0,019$ & 0,034 & $-0,558$ & 0,578 \\
\hline$X_{5}$ & 0,248 & 0,742 & 0,335 & 0,738 \\
\hline
\end{tabular}

Berdasarkan hasil tersebut dapat diperoleh persamaan regresi linier berganda sebagai berikut:

$$
Y=2,560+0,028 X_{1}+0,023 X_{2}-0,025 X_{3}-0,019 X_{4}+0,248 X_{5}
$$

\section{Uji validitas pengaruh (uji hipotesis)}

Hasil perhitungan uji t dapat diketahui besarnya pengaruh masing-masing variabel bebas terhadap variabel terikat sebagai berikut: 
a. Pengaruh variabel Pengetahuan Awal $\left(X_{1}\right)$ terhadap Pemahaman Akuntansi $(Y) t$ hitung untuk variabel pengetahuan awal $\left(X_{1}\right)$ memiliki nilai probabilitas $<$ a yaitu $0,04<0,05$. Karena probabilitasnya lebih kecil dari $5 \%$, maka berarti variable Pengetahuan awal $\left(X_{1}\right)$ secara parsial mempunyai pengaruh signifikan terhadap Pemahaman Akuntansi (Y), sehingga $\mathrm{H} 1$ dalam penelitian ini tidak ditolak

b. Pengaruh variabel Efikasi Diri $\left(\mathrm{X}_{2}\right)$ terhadap Pemahaman Akuntansi $(\mathrm{Y}) \mathrm{t}$ hitung untuk variabel Efikasi Diri lebih besar dari probabilitas a yaitu 0,356 yang berarti variable Efikasi diri $\left(\mathrm{X}_{2}\right)$ secara parsial tidak pengaruh signifikan terhadap Pemahaman Akuntansi $(\mathrm{Y})$, sehingga $\mathrm{H} 2$ dalam penelitian ini ditolak

c. Pengaruh variabel Kecerdasan Emosional $\left(\mathrm{X}_{3}\right)$ terhadap Pemahaman Akuntansi (Y) memiliki nilai probabilitas $>$ a yaitu 0,404 $>0,05$. Karena nilai probabilitasnya lebih besar dari 5\%, maka variable Kecerdasan Emosional $\left(\mathrm{X}_{3}\right)$ secara parsial mempunyai pengaruh tidak signifikan terhadap Pemahaman Akuntansi $(Y)$, sehingga $\mathrm{H} 3$ dalam penelitian ini ditolak

d. Pengaruh variabel Perilaku Belajar $\left(\mathrm{X}_{4}\right)$ terhadap Pemahaman Akuntansi $(\mathrm{Y})$ memiliki nilai probabilitas $>$ a yaitu $0,578>0,05$. Karena nilai probabilitasnya lebih besar dari 5\%, maka variable Perilaku Belajar $\left(\mathrm{X}_{4}\right)$ secara parsial mempunyai pengaruh tidak signifikan terhadap Pemahaman Akuntansi $(\mathrm{Y})$, sehingga $\mathrm{H} 4$ dalam penelitian ini ditolak

e. Pengaruh variabel Budaya $\left(\mathrm{X}_{5}\right)$ terhadap Pemahaman Akuntansi $(\mathrm{Y})$ memiliki nilai probabilitas $>$ a yaitu $0,738>0,05$. Karena nilai probabilitasnya lebih besar dari $5 \%$, maka variable Budaya $\left(X_{5}\right)$ secara parsial mempunyai pengaruh tidak signifikan terhadap Pemahaman Akuntansi (Y), sehingga H5 dalam penelitian ini ditolak

\subsection{Pembahasan}

Setelah dilakukan pengujian statistik secara parsial (individu) dengan menggunakan uji t, maka analisis lebih lanjut dari hasil analisis regresi adalah:

\section{Pengaruh pengetahuan awal terhadap pemahaman akuntansi}

Hasil uji regresi menunjukkan variabel pengetahuan awal berpengaruh dan signifikan terhadap pemahaman akuntansi dengan koefisien 0,028. Hal ini berarti dengan semakin tinggi pengetahuan awal akuntansi maka pemahaman akuntansi juga akan meningkat. Hasil penelitian ini mendukung hasil penelitian terdahulu yaitu penelitian Fathurrochman (2012) dan (Handayani, 2017) hasil penelitian menunjukkan bahwa secara simultan terdapat pengaruh positif dan signifikan antara pengetahuan awal siswa pemahaman akuntansi. Hal ini berasal dari faktor intern dan faktor exstern. Faktor intern berhubungan dengan segala sesuatu yang ada pada diri sementara berhubungan dengan hal yang berasal dari luar diri pembelajar seperti pengalaman, lingkungan sosial, metode balajar, strategi belajar, fasilitas belajar dan peran guru. Keberhasilan dalam mencapai suatu tahap hasil belajar memungkinkannya untuk belajar lebih lancar dalam mencapai tahap selanjutnya. Namun hal ini tidak mendukung temuan Taufiq (2017) yang tidak dapat menemukan hubungan antara pengetahuan awal dengan pemahaman akuntansi dikarenakan pemahaman lebih dibentuk dari strategi pembelajaran untuk membentuk pemahaman mahasiswa. 


\section{Pengaruh efikasi diri terhadap pemahaman akuntansi}

Adapun pengaruh variable efikasi diri terhadap pemahaman akuntansi mendapati hasil yang tidak signifikan dengan nilai koefisien 0,356 yang lebih besar dari 0,05. Hal ini menandakan bahwa semakin tinggi efikasi diri tidak dapat mempengaruhi pemahaman akuntansi. Hal ini sejalan dengan penelitian Budiadi dan Sulistyawati (2013) yang menyatakan bahwa efikasi diri tidak dapat mempengaruhi pemahaman akuntansi. Efikasi diri adalah pertimbangan subjektif individu terhadap kemampuannya untuk menyusun tindakan yang dibutuhkan untuk menyelesaikan tugas-tugas khusus yang dihadapi seseorang (Bandura, 1997). Hal ini dapat disebabkan karena rendahnya tingkat efikasi mahasiswa perbankan IAIN Salatiga sehingga menyebabkan tidak dapat membantu memahami akuntansi. Penelitian ini menolak hasil yang diperoleh dari penelitian Taufiq (2017) yang menyatakan bahwa efikasi diri berpengaruh positif signifikan terhadap minat belajar akuntansi pada mahasiswa jurusan akuntansi.

\section{Pengaruh kecerdasan emosional terhadap pemahaman akuntansi}

Variabel kecerdasan emosional seharusnya mampu meningkatkan pemahaman akuntansi. Kecerdasan emosional menuntut diri untuk belajar mengakui dan menghargai perasaan diri sendiri dan orang lain dan untuk menanggapinya dengan tepat, menerapkan dengan efektif energi emosi dalam kehidupan dan pekerjaan sehari-hari. Namun penelitian ini tidak dapat membuktikan hubungan antara kecerdasan emosional dengan pemahaman akuntansi dengan nilai signifikansi 0,404. Hal ini dapat dapat disebabkan karena banyak factor diluar kecerdasan emosional yang dapat mempengaruhi pemahaman akuntansi (Zakiyah, 2013). Hasil penelitian ini sejalan dengan penelitian yang dilakukan oleh Dwijayanti (2009) yang menyatakan bahwa orang yang hanya memiliki kecerdasan intelektual saja atau banyak memiliki gelar tinggi belum tentu sukses berkiprah di dunia pekerjaan. Bahkan sering kali yang berpendidikan formal lebih rendah ternyata banyak yang lebih berhasil. Hal ini tidak sejalan dengan penelitian yang dilakukan oleh Devi et al. (2019) yang menyatakan bahwa kecerdasan emosional berpengaruh positif pada tingkat pemahaman akuntansi dikarenakan semakin tinggi tingkat kecerdasan emosional yang dimiliki mahasiswa akuntansi maka mahasiswa tersebut akan semakin paham mengenai akuntansi.

\section{Pengaruh perilaku belajar terhadap pemahaman akuntansi}

Perilaku belajar dapat diartikan sebagai upaya untuk memusatkan perhatian kepada dosen, materi dengan cara membuat catatan atau pertanyaan serta berbagai upaya lain guna menyerap dan memahami penugasan yang diberikan oleh dosen (Parauba, 2014). Namun penelitian ini belum dapat membuktikan hubungan yang signifikan antara perilaku belajar dan pemahaman akuntansi pada mahasiswa perbankan Syariah IAIN Salatiga. Hal ini dapat disebabkan karena minat baca dan kunjungan ke perpustakaan yang kurang sehingga menjadi salah satu factor penghambat pengetahuan tentang informasi akuntansi (Agustin \& Sujana, 2018). Namun demikian penelitian ini tidak sejalan dengan hasil yang diperoleh (Holly et al., 2011) yang berhasil membuktikan pengaruh yang signifikan antara perilaku belajar dengan pemahaman akuntansi, yang berarti bahwa proses belajar yang dilakukan mahasiswa dalam bentuk apapun akan mempengaruhi pemahaman akuntansinya. 


\section{Pengaruh budaya terhadap pemahaman akuntansi}

Variabel budaya pada penelitian ini diukur dengan variable dummy dengan skor 1 untuk suku jawa dan 0 untuk suku non jawa. Hal ini disebabkan karena setiap suku memiliki cara tersendiri dalam proses belajar guna mengimplementasikan aktivitas kehidupan budaya itu sendiri (Tjun et al., 2009). Namun penelitian ini tidak dapat membuktikan pengaruh budaya terhadap pemahaman akuntansi dengan nilai signifikansi diata 5\% yaitu 0,578. Hal ini sejalan dengan temuan Tjun et al. (2009), (Widyawati et al., 2014), Suprianto \& Harryoga (2016) yang tidak dapat menemukan hubungan antara budaya dengan pemahaman akuntansi.

Namun temuan ini tidak sejalan dengan temuan (Fallis, 2013) yang mampu membuktikan hubungan antara budaya dengan pemahaman akuntansi dengan indicator pengukuran budaya dengan kepemimpinan. Kepemimpinan ini memicu adanya disiplin, pergaulan dan pembelajaran yang membuat mahasiswa dapat berperilaku baik sehingga dapat memahami materi dengan sangat baik karena dukungan lingkungan tersebut.

\section{Kesimpulan}

Berdasarkan uraian-uraian yang telah diungkapkan pada pembahasan, maka dapat diambil beberapa kesimpulan bahwa Pengetahuan awal berpengaruh terhadap pemahaman akuntansi. Sementara Efikasi diri, kecerdasan emosional, dan kecerdasan spiritualefikasi diri, kecerdasan emosional, perilaku budaya dan budaya tidak berpengaruh terhadap pemahaman akuntansi.

Dalam melaksanakan penelitian ini ada beberapa hal yang menjadi kendala dan menyulitkan bagi peneliti untuk melakukan penelitian ini, yaitu: 1) Terbatasnya variabel yang digunakan dalam model, serta banyak variabel yang tidak signifikan, 2) Pemilihan sampel dalam penelitian ini menggunakan metode purposive sampling sehingga mahasiswa yang dijadikan sebagai sampel menjadi terbatas pada kriteria-kriteria yang telah ditetapkan yaitu mahasiswa perbankan Syariah semester 5 IAIN Salatiga.

\section{Ucapan Terimakasih}

Penulis mengucapakan banyak terimakasih kepada IAIN Salatiga yang sudah memberikan hibah penelitian, sehingga penelitian ini dapat terselesaikan.

\section{Referensi}

Adicondro, Nobelina dan Purnamasari Alfi. 2011. Efikasi Diri, Dukungan Sosial Keluarga dan Self Regulated Learning pada Mahasiswa Kelas VIII. Jurnal Humanitas. Vol. VIII. No. 01.

Nugraha, A. P. 2013. Pengaruh Kecerdasan Emosional dan Perilaku Belajar terhadap Tingkat Pemahaman Akuntansi. Skripsi Universitas Jember.

Bandura, Albert. 1997. Self Efficacy The Exercise of Control, First Edition. Freeman: New York. 
Bloom, B. S. (1984). The 2 sigma problem: The search for methods of group instruction as effective as one-to-one tutoring. Educational researcher, 13(6), 4-16.

Goleman, D. 1995. Emotional intelligence: Why It can matter more Than IQ? New York: Bantom Books

Hariyoga, S., dan Suprianto, E. 2011. Pengaruh Kecerdasan emosional, perilaku belajar, dan budaya terhadap tingkat pemahaman akuntansi dengan kepercayaan diri sebagai variabel pemoderasi. Simposium Nasional Akuntansi $X I V$.

Hikmawati, E. (2019). Pengaruh Kecerdasan Emosional, Kecerdasan Intelektual, Perilaku Belajar, Dan Budaya Terhadap Tingkat Pemahaman Akuntansi Dengan Kepercayaan Diri Sebagai Variabel Pemoderasi (Studi Pada Mahasiswa Akuntansi Universitas Muhammadiyah Jember Angkatan Tahun 2016-2018) (Doctoral Dissertation, Universitas Muhammadiyah Jember).

Hofstede, G. 1980. Culture's Consequences. Beverly Hills, CA: Sage.

Kujawa, S., \& Huske, L. (1995). Strategic teaching and reading project guidebook. NCREL.

Mawardi, M. K. 2011. The Factors of SME Cluster Development in a Developing Country: The Case of Indonesian Clusters ICSB World Conference. Stockholm, Sweden

Parauba, I. 2014. Pengaruh kecerdasan intelektual, kecerdasan emosional, kecerdasan spiritual, dan perilaku belajar terhadap pemahaman akuntansi mahasiswa fakultas ekonomi dan bisnis universitas sam ratulangi manado. GOING CONCERN: JURNAL RISET AKUNTANSI, 9(2).

Sar'i, Muhammad, Muhammad Irsadsyah, Nasrullah Djamil. 2010. Analisis Tingkat Pemahaman Mahasiswa Akuntansi Terhadap Konsep Dasar Akuntansi (Studi Empiris Pada Mahasiswa Akuntansi S1 UIN SUSKA Riau Yang Berasal Dari Latar Belakang Sekolah Menengah Yang Berbeda). Purwokerto: Simposium Nasional Akuntansi XIII. Vol 13.

Suryaningrum, Sri. 2013. Penalaran Atas Persamaan Akuntansi Vs Persamaan Matematika. Jurnal Akuntansi \& Keuangan. Vol. 4(1) pp. 19-23.

Suwardjono. 1999. Memahamkan Akuntansi di Tingkat Pengantar. Jurnal Ekonomi dan Bisnis Indonesia. Jurnal Ekonomi dan Bisnis Indonesia. Vol. 14, No. 1, 7187

Suwardjono. 2001. Mamahamkan Akuntansi Dengan Penalaran dan Pendekatan Sistem. Jurnal Ekonomi dan Bisnis Indonesia, Vol. 14 No.3, pp.106-122

Suwardjono. 2010. Teori Akuntansi Perekayasa Pelaporan Keuangan. Yogyakarta : BPFE. Cetakan keempat.

Trisnawati, Eka Indah dan Sri Suryaningrum. 2003. Pengaruh Kecerdasan Emosional Terhadap Tingkat Pemahaman Akuntansi. Prosiding. Simposium Nasional Akuntansi, Surabaya

Taylor, SE. 2009. Health Physychology. Seventh Edition. Singapore: Mc. Graw Hill

Taufiq, M. .2017. Pengaruh Pengetahuan Awal Akuntansi Dan Efikasi Diri Terhadap Tingkat Pemahaman Akuntansi Melalui Minat Belajar Pada Mahasiswa Jurusan 
Akuntansi Universitas Pgri Adi Buana Surabaya. Jurnal Ekonomi Pendidikan dan Kewirausahaan, 3(2).

Wardhani, I. R. 2012. Pengaruh kecerdasan emosional, perilaku belajar, dan budaya terhadap tingkat pemahaman akuntansi pada mahasiswa jurusan akuntansi di Universitas Muhammadiyah Surakarta (Doctoral dissertation, Universitas Muhammadiyah Surakarta).

Wingkel. 1987. Psikologi Pengajaran. Jakarta: Gramedia.

Woolfolk, A. 2007. Educational Psychology. USA: Pearson Education, Inc.

Zakiah, F. (2013). Pengaruh Kecerdasan Intelektual, Kecerdasan Emosional Dan Kecerdasan Spiritual Terhadap Pemahaman Akuntansi.

Zimmerman, B.J. (2008). Investigating self-regulation and motivation: Historical background, methodological developments, and future prospects. American Education Research Journal, 45, 166-183

Ayu Arisanti, Devika dan Hakim, L. (2019). Pengaruh Efikasi Diri, Regulasi Diri Dan Kebiasaan Belajar Terhadap Hasil Belajar Akuntansi Biaya Mahasiswa Prodi Pendidikan Akuntansi Universitas Negeri Surabaya. Jurnal Pendidikan Akuntansi (Jpak), 7(3). 